\title{
Arsenic Accumulation in Grafted Melon Plants: Role of Rootstock in Modulating Root-To-Shoot Translocation and Physiological Response
}

\author{
Enrica Allevato ${ }^{1,+}+\mathbb{D}$, Rosario Paolo Mauro ${ }^{2,+}\left(\mathbb{D}\right.$, Silvia Rita Stazi ${ }^{3, *(\mathbb{D}}$, Rosita Marabottini $^{1}{ }^{(\mathbb{D}}$, \\ Cherubino Leonardi ${ }^{2}$, Anita Ierna ${ }^{4}(\mathbb{D})$ and Francesco Giuffrida ${ }^{2}$ \\ 1 DIBAF, University of Tuscia, Via S.C. De Lellis snc, 01100 Viterbo, Italy; eallevato@unitus.it (E.A.); \\ marabottini@unitus.it (R.M.) \\ 2 Di3A, University of Catania, Via Valdisavoia 5, 95123 Catania, Italy; rosario.mauro@unict.it (R.P.M.); \\ cherubino.leonardi@unict.it (C.L.); francesco.giuffrida@unict.it (F.G.) \\ 3 DSCF, University of Ferrara, Via Borsari 46, 44121 Ferrara, Italy \\ 4 CNR-IBE, Via P. Gaifami 18, 95126 Catania, Italy; anita.ierna@cnr.it \\ * Correspondence: silviarita.stazi@unife.it \\ + The authors share the first Authorship.
}

Received: 6 October 2019; Accepted: 26 November 2019; Published: 1 December 2019

\begin{abstract}
The bio-agronomical response, along with the arsenic (As) translocation and partitioning were investigated in self-grafted melon "Proteo", or grafted onto three interspecific ("RS841", "Shintoza", and "Strong Tosa") and two intraspecific hybrids ("Dinero" and "Magnus"). Plants were grown in a soilless system and exposed to two As concentrations in the nutrient solution (0.002 and $3.80 \mathrm{mg} \mathrm{L}^{-1}$, referred to as As- and As+) for 30 days. The As+ treatment lowered the aboveground dry biomass $(-8 \%$, on average), but the grafting combinations differed in terms of photosynthetic response. As regards the metalloid absorption, the rootstocks revealed a different tendency to uptake As into the root, where its concentration varied from 1633.57 to $369.10 \mathrm{mg} \mathrm{kg}^{-1} \mathrm{DW}$ in "Magnus" and "RS841", respectively. The high bioaccumulation factors in root (ranging from 97.13 to 429.89 ) and the low translocation factors in shoot (from 0.015 to 0.071 ) and pulp (from 0.002 to 0.008 ) under As+, showed a high As mobility in the substrate-plant system, and a lower mobility inside the plants. This tendency was higher in the intraspecific rootstocks. Nonetheless, the interspecific "RS841" proved to be the best rootstock in maximizing yield and minimizing, at the same time, the As concentration into the fruit.
\end{abstract}

Keywords: Cucumis melo L.; arsenic; grafting; translocation; bioaccumulation

\section{Introduction}

Melon (Cucumis melo L.) is one of the major Cucurbit species, playing an important role in irrigated farmlands of the Mediterranean area [1]. In these regions, the water intended for irrigation could be contaminated with heavy metals as result of weathering of soil minerals and human activities [2]. Irrigation with contaminated water can affect food quality and safety for the presence of metalloids and/or heavy metals harmful for human health [3,4]. Among these, arsenic (As) is a persistent, non-degradable metalloid widely present in the environment both for geogenic or anthropogenic reasons [5]. Most As compounds are odorless, tasteless, and water-soluble, creating a serious health risk because of their carcinogenic potential [6]. This metalloid exists in plant organs both as inorganic and organometallic species, whose concentration and oxidation states are dependent on the type and amounts of sorbents in the substrate, $\mathrm{pH}$, redox potential (Eh), and soil microbial activity $[7,8]$. 
Arsenic is non-essential and generally toxic to plants. At high concentrations (depending on the species) it interferes with multiple metabolic processes, leading to growth and yield disturbance, and even plant death $[9,10]$. The As(III) root uptake (i.e., the dominating form in anaerobic root environments) occurs by passive transmembrane transport involving members of the nodulin 26-like intrinsic protein family of plant aquaporins [11]. As $(\mathrm{V})$, which dominates in aerobic root environments, enters plant roots via phosphate $(\mathrm{Pi})$ transporters, as the oxyanion chemical structure of $\mathrm{As}(\mathrm{V})$ is analogous to $\mathrm{Pi}$ [12]. As a consequence, $\mathrm{As}(\mathrm{V})$ compete with Pi absorption and P-dependent metabolic processes during ATP synthesis, with subsequent disturbance of major biological functions $[13,14]$.

The efficiency of As translocation from roots to shoots via xylem loading affects the plants' As tolerance and their proneness to accumulate this metalloid into the edible fraction, so posing potential risks to human health [14].

In horticultural systems, vegetable grafting is a multipurpose technique improving crops performances and product quality under both optimal and suboptimal growth conditions [15-17]. It has been proposed as a means to reduce the heavy metals uptake and translocation to the shoots and the edible parts [18,19], although the mechanisms underlying such impediment are still unclear [20]. Thus, investigating the use of melon rootstocks could be useful for understanding the behavior of different grafting combinations, with the view to improve crop performances and product safety in As-polluted areas.

Considering the above, the objective of this research was to study the effects of different rootstock genotypes on As uptake, accumulation, and partitioning, as well as on agronomical and physiological response of melon plants subjected to a high concentration of the metalloid in the root environment. To this end, the present experiment was performed to investigate: (i) If As concentration in the nutrient solution influences its uptake and translocation in melon plants; (ii) if and how the different rootstocks can mitigate the As accumulation within plant organs; (iii) the possible role of different rootstock genotypes in modulating the bio-agronomical response of melon plants to the elevated As concentration in the root zone.

\section{Materials and Methods}

\subsection{Experimental Site, Plant Material, and Management Practices}

The experiment was conducted in 2014, in a greenhouse situated in the coastal area of Eastern Sicily $\left(37^{\circ} 24^{\prime} 26^{\prime \prime} \mathrm{N}, 15^{\circ} 03^{\prime} 37^{\prime \prime} \mathrm{E}, 6 \mathrm{~m}\right.$ a.s.l.). The local climate is semi-arid/Mediterranean, with mild and wet winters, and hot, dry summers. A $1000 \mathrm{~m}^{2}$, east-west-oriented, multi-aisle greenhouse was used, having a steel tubular structure and covered with polycarbonate slabs. Mean air temperature, relative humidity and global radiation inside the greenhouse (two sets of sensors in the center of each experimental plot) were recorded on a data logger (CR10 X; Campbell Scientific Ltd., Loughborough, UK). Melon cv. "Proteo" $F_{1}$ (Syngenta Seed, Basel, Switzerland) belonging to the Reticulatus group was used as scion. Five $F_{1}$ rootstock genotypes were included in the study, of which 2 were intraspecific, namely "Dinero" (Syngenta Seed) and "Magnus" (Agris), and 3 were interspecific (Cucurbita maxima Duchesne $\times$ C. moschata Duchesne ex Poir.), namely "RS841" (DeRuiter Seeds, Oxnard, CA, USA) "Shintoza" (Fenix, Belpasso, Italy) and 'Strong Tosa' (Syngenta Seed). Self-grafted "Proteo" was used as control. Splice-grafted plantlets were used, whereas plastic clips were applied to secure the creation of the graft union. Plantlets were obtained from a specialized nursery and transplanted at the stage of 3 true leaves on April 22, in $5 \mathrm{~L}$ pots filled with perlite $(3-5 \mathrm{~mm})$. Pots were placed in troughs ( 5 per main plot) of an open soilless system, placed at $5 \mathrm{~cm}$ from the soil surface and with a distance of 50 $\mathrm{cm}$ between pots and $100 \mathrm{~cm}$ between troughs, obtaining a plant density of 2 plants $\mathrm{m}^{-2}$. During the trial, the crop was fertigated with a nutrient solution having the following composition, including the starting well water $\left(\mathrm{mmol} \mathrm{L}{ }^{-1}\right): 11.2 \mathrm{NO}_{3}{ }^{-}, 0.3 \mathrm{NH}_{4}{ }^{+}, 1.3 \mathrm{H}_{2} \mathrm{PO}_{4}{ }^{-}, 6.6 \mathrm{~K}^{+}, 0.9 \mathrm{SO}_{4}{ }^{2-}, 3.4 \mathrm{Ca}^{2+}$, $2.5 \mathrm{Mg}^{2+}$. The concentration of microelements $\left(\mu \mathrm{mol} \mathrm{L}{ }^{-1}\right.$ ) was: $15 \mathrm{Fe}^{3+}, 10 \mathrm{Mn}^{2+}, 0.75 \mathrm{Cu}^{2+}, 5 \mathrm{Zn}^{2+}$, $30 \mathrm{~B}^{3+}, 0.5 \mathrm{Mo}^{6+}$. The $\mathrm{pH}$ was maintained at 5.9 by adding $\mathrm{H}_{2} \mathrm{SO}_{4}\left(95 \%\right.$ concentration, $\left.1.83 \mathrm{~kg} \mathrm{~L}^{-1}\right)$. 
Bumblebees were introduced into the greenhouse to maximize pollination. Stems were left to grow horizontally, whereas plants were pruned by removing the lateral shoots. Only 1 lateral ramification per plant was left, bearing 2 fruits. In order to evaluate the effects of studied factors at the same date, the trial was stopped when the first fruit was fully ripe (i.e., 45 days after transplant). Fifteen days after transplanting, the nutrient solution was differentiated to obtain 2 As concentrations, a control solution $\left(0.002 \mathrm{mg} \mathrm{L}^{-1}\right.$ As, which was the concentration in the starting fertigation solution, hereafter As-) and an As-enriched one (3.8 $\mathrm{mg} \mathrm{L}^{-1}$ As, hereafter As+) obtained by adding sodium arsenate $\left(\mathrm{Na}_{2} \mathrm{HAsO}_{4}\right.$ $7 \mathrm{H}_{2} \mathrm{O}, 24 \%$ As content). The As+ treatment was chosen to simulate the working condition of a soil having $55 \mathrm{ppm}$ of As, $7.0 \%$ of which was bioavailable (a common situation in As contaminated soils). The nutrient solutions were supplied using a drip irrigation system with one emitter per plant $\left(4 \mathrm{~L} \mathrm{~h}^{-1}\right)$. The amount of nutrient solution supplied at each irrigation was quantified on a weekly basis, according to the volume of the substrate exploited by the roots and the corresponding water contained in the substrate at the intervals from -10 to $-50 \mathrm{hPa}$ of matrix potential $\left(12 \mathrm{~mL} 100 \mathrm{~mL}^{-1}\right)$.

The experiment was arranged in a randomized split-plot design with three replicates, assigning the As concentration of the nutrient solution to the main plots, and the rootstock combination to the subplots. The overall experimental area inside the greenhouse was $450 \mathrm{~m}^{2}(15.0 \times 30.0 \mathrm{~m})$, including 900 plants (324, excluding border plants), divided into 36 net experimental units ( 2 As levels $\times 6$ grafting combinations $\times 3$ replicates) each containing 9 plants.

\subsection{Leaf Relative Chlorophyll (Chl) Content and Gas Exchange Measurements}

Forty-five days after transplanting plants were checked for leaf relative $\mathrm{Chl}$ content, through a portable Chl meter (SPAD 502; Minolta Camera, Osaka, Japan). Before measurements, the instrument was calibrated according to manufacturer's instructions. All readings were taken from the adaxial side of the tallest fully expanded leaf. To minimize possible interactions with either plant water status and natural irradiance level [21,22], measurements were made in the morning, starting at 08:00 $\mathrm{h}$ (local solar time). Instantaneous leaf photosynthetic rate $\left(\mathrm{A}_{\mathrm{N}}\right)$, stomatal conductance (gs), and leaf transpiration rate (E) were also measured from 11:00 to 13:00 inside a $6.25 \mathrm{~cm}^{2}$ leaf chamber of a portable photosynthesis system (LCi; ADC BioScientific Ltd., Hoddesdon, UK). Photosynthetic water use efficiency (WUE) was calculated as the ratio $\mathrm{A}_{N} / \mathrm{E}$ [23]. During measurements, leaf temperature was $27.4 \pm 2{ }^{\circ} \mathrm{C}$, while mean photosynthetic photon flux density was in the range of $1500 \pm 100 \mu \mathrm{mol}$ photons $\mathrm{m}^{-2} \mathrm{~s}^{-1}$. Duplicate measurements were taken from four plants per sub-plot.

\subsection{Plant Growth and Development Measurements}

On the same date of physiological measurements, all the plants within each replicate were harvested and their main fractions (leaves, stem and fruits, regardless of the ripening stage) weighed separately. The number of leaves per plant $\left(\mathrm{L}_{\mathrm{N}}\right)$ was determined, while plant leaf area $\left(\mathrm{L}_{\mathrm{A}}\right)$ was measured using an Image Analysis System (DeltaT Devices Ltd., Cambridge, UK), then subsamples of raw materials were kept in a thermo-ventilated oven at $70{ }^{\circ} \mathrm{C}$ (Binder, Milan, Italy) until constant weight, in order to determine their dry weight (DW). From the original data frame, the leaf area ratio (LAR, the ratio between the area and total plant biomass) and leaf weight ratio (LWR, the dry weight of leaves to whole plant dry weight) were calculated.

\subsection{Arsenic and Phosphorous Determination in Plant Tissues}

Roots, shoots, and fully ripe fruits (1 per plant) were analyzed to determine the quantity of the total As and phosphorus (P). To this end, about $200 \mathrm{mg}$ of samples were subjected to acid digestions and to As and P determinations, which were performed according to Stazi et al. [19]. The reagents were super pure for trace analysis. The accuracy of the measurements was assessed using SRM 1573a as standard reference materials trace metals. Total As quantification were performed using an inductively-coupled plasma optical emission spectrometer (ICP-OES) with an axially viewed configuration (8000 DV, PerkinElmer, Shelton, CT, USA) equipped with an ultrasonic nebulizer. The As detection limit for 
employed technique was $0.1 \mu \mathrm{g} \mathrm{L} \mathrm{L}^{-1}$. With the aim of understanding the metabolic pathway followed by this element once absorbed by the plant, we measured the amount of trivalent and pentavalent As. Inorganic As species were extracted without the addition of hydrogen peroxide according to Rintala et al. [24] with some modifications. In brief, $200 \mathrm{mg}$ of roots were homogenized and digested with $10 \mathrm{~mL}$ of a mixture of $\mathrm{HNO}_{3}(1 \%, \mathrm{v} / \mathrm{v})$ and left to react overnight. The samples were subjected to microwave-assisted extraction according to the following program $-3 \mathrm{~min}$ from 25 to $55^{\circ} \mathrm{C}$ (step 1), $10 \mathrm{~min}$ at $55^{\circ} \mathrm{C}$ (step 2), $2 \mathrm{~min}$ from 55 to $75^{\circ} \mathrm{C}$ (step 3), $10 \mathrm{~min}$ at $75^{\circ} \mathrm{C}$ (step 4), 2 min from 75 to $95^{\circ} \mathrm{C}$ (step 5) and $30 \mathrm{~min}$ at $95^{\circ} \mathrm{C}$ (step 6). Samples were then quantitatively transferred into tubes and centrifuged for $15 \mathrm{~min}$ at $10,000 \mathrm{rpm}$ at $4{ }^{\circ} \mathrm{C}$. The supernatant was filtered with a $0.22 \mu \mathrm{m}$ PVDF filter. The concentration of As(III) was determined directly with an ICP-OES equipped with a hydride generation system. The total concentration of inorganic arsenic species $[\mathrm{As}(\mathrm{III})+\mathrm{As}(\mathrm{V})]$ were obtained after reducing $\mathrm{As}(\mathrm{V})$ to $\mathrm{As}(\mathrm{III})$ through $5.0 \%(\mathrm{w} / \mathrm{v})$ ascorbic acid and potassium iodide in hydrochloric acid, and the content of $\mathrm{As}(\mathrm{V})$ was calculated from the difference between total As concentration and that of As(III) [25].

\subsection{Bioaccumulation and Translocation Factors}

Arsenic bioaccumulation factor (BAF) (i.e., the ability of a plant to accumulate this element from water) was calculated on a DW basis, as the ratio among its concentration in root $\left(\mathrm{BAF}_{\text {root }}\right)$, shoot $\left(\mathrm{BAF}_{\text {shoot }}\right)$, and pulp $\left(\mathrm{BAF}_{\text {pulp }}\right)$ and the corresponding concentration in the nutrient solution. The root-to-plant translocation factor (TF) defines the movement and distribution of As from roots to the aerial part of the plant. The TF was calculated on a DW basis, as the ratio between the As concentration in shoot $\left(\mathrm{TF}_{\text {shoot }}\right)$ and fruit pulp $\left(\mathrm{TF}_{\text {pulp }}\right)$, and the corresponding concentration in roots at the end of the experiment [26-28].

\subsection{Statistical Procedures}

All data were subjected to Shapiro-Wilk and Levene's test, in order to check for normal distribution and homoscedasticity, respectively, then to a 'As concentration $\times$ rootstock' analysis of variance (ANOVA), according to the split-plot experimental layout adopted in the greenhouse. Percentage data were Bliss' transformed before the ANOVA (untransformed data are reported and discussed), while multiple means comparison was performed through Fisher's protected least significant difference (LSD) test $(p=0.05)$. The As concentrations in root, shoot, and pulp were subjected at principal component analysis (PCA) to verify the interaction between the different factors able to synthetize the considered variables. All calculations were performed using the Excel (Microsoft Corporation, Redmond, WA, USA) and JMP 11.0 statistical software package (SAS Institute, Cary, NC, USA).

\subsection{Microclimate Conditions Inside the Greenhouse}

During the experiment, the average mean temperature progressively increased from 18.6 to $26.4{ }^{\circ} \mathrm{C}$ (on day 12 and 36 after transplanting, respectively), while relative humidity showed an opposite trend, as it passed from $63.7 \%$ to $40.5 \%$ (on day 11 and 33 after transplanting, respectively). Solar radiation amply paralleled the trend of mean temperature, as it progressively increased passing from 10.45 to $15.02 \mathrm{MJ} \mathrm{m}^{-2}$ (on day 11 and 36 after transplanting, respectively). As regards the spatial variability among main plots, the differences in terms of mean temperature, relative humidity, and solar radiation never exceeded $0.2{ }^{\circ} \mathrm{C}, 2.1 \%$, and $0.8 \mathrm{MJ} \mathrm{m}^{-2}$, respectively.

\section{Results}

\subsection{Aboveground Plant Biomass and Partitioning}

Whole plant biomass was affected by the main factors and their interaction (Table 1). In Astreatment this variable was higher in "Proteo" grafted onto "Strong Tosa" and "RS841" (309 g plant ${ }^{-1}$, on average), whereas in response to As+ treatment it significantly decreased in "Proteo" grafted onto 
"Dinero" (from 251.7 to 198.7 g plant $^{-1},-21 \%$ ) and "Strong Tosa" (from 317.0 to 239.3 g plant $^{-1},-25 \%$ ) (Table 1). Among the plant components, stem biomass resulted 30 and $24 \mathrm{~g} \mathrm{plant}^{-1}$ in As- and Ast, respectively $(-20 \%)$ (Table 1$)$. Passing from As- to As+, there was a general decrease of the leaf biomass too. This response was more marked in "Proteo" grafted onto "Dinero" (from 66.4 to $42.0 \mathrm{~g}$ plant $^{-1},-37 \%$ ), 'Magnus' (from 56.7 to $44.5 \mathrm{~g} \mathrm{plant}^{-1},-22 \%$ ), 'RS841' (from 66.3 to $52.1 \mathrm{~g} \mathrm{plant}^{-1}$, $-21 \%$ ), and "Strong Tosa" (from 58.0 to $44.4 \mathrm{~g} \mathrm{plant}^{-1},-23 \%$ ), whereas no significant difference was recorded when "Proteo" was self-grafted or grafted onto "Shintoza" (Table 1). When grown in the As+, fruit biomass showed a significant variation in "Proteo" grafted onto 'Magnus' and "Strong Tosa", where it varied by $+33 \%$ (from 119.9 to $159.1 \mathrm{~g} \mathrm{plant}^{-1}$ ) and $-26 \%$ (from 231.1 to $170.9 \mathrm{~g} \mathrm{plant}^{-1}$ ), respectively (Table 1).

Table 1. Aboveground biomass production and partitioning ( $\mathrm{g}$ dry weight plant ${ }^{-1}$ ) in melon plant as affected by As concentration in the nutrient solution and rootstock. Different letters within main factors indicate significance at Fisher's protected least significant difference (LSD) test $(p=0.05)$. NS-not significant.

\begin{tabular}{|c|c|c|c|c|c|c|c|c|c|}
\hline \multirow{2}{*}{\multicolumn{2}{|c|}{ Variable }} & \multicolumn{6}{|c|}{ Rootstock } & \multirow[b]{2}{*}{ Mean } & \multirow{2}{*}{$\begin{array}{l}\text { LSD }_{\text {interaction }} \\
\quad(p=0.05)\end{array}$} \\
\hline & & $\begin{array}{l}\text { "Proteo" } \\
\text { (Control) }\end{array}$ & "Dinero" & "Magnus" & "RS841” & "Shintoza" & "Strong Tosa" & & \\
\hline \multirow{3}{*}{ Plant } & As- & 235.0 & 251.7 & 207.0 & 300.3 & 247.7 & 317.0 & 259.8 a & 45.1 \\
\hline & As+ & 220.0 & 198.7 & 226.3 & 278.7 & 268.3 & 239.3 & $238.6 \mathrm{~b}$ & \\
\hline & Mean & $227 \mathrm{bc}$ & $225 c$ & $217 c$ & 289 a & $258 \mathrm{ab}$ & 278 a & & \\
\hline \multirow{3}{*}{ Stem } & As- & 29.7 & 31.2 & 31.4 & 29.6 & 30.8 & 28.0 & $30.1 \mathrm{a}$ & NS \\
\hline & As+ & 22.2 & 21.9 & 22.7 & 25.0 & 28.4 & 23.39 & $24.0 \mathrm{~b}$ & \\
\hline & Mean & $25.9 \mathrm{a}$ & $26.5 \mathrm{a}$ & 27.1 a & $27.3 \mathrm{a}$ & $29.6 \mathrm{a}$ & $25.9 \mathrm{a}$ & & \\
\hline \multirow{3}{*}{ Leaf } & As- & 56.8 & 66.4 & 56.7 & 66.3 & 55.8 & 58.0 & $60.0 \mathrm{a}$ & 10.3 \\
\hline & As+ & 47.6 & 42.0 & 44.5 & 52.1 & 58.0 & 44.4 & $48.1 \mathrm{~b}$ & \\
\hline & Mean & $52.2 \mathrm{a}$ & $54.2 \mathrm{a}$ & $50.6 \mathrm{a}$ & $59.2 \mathrm{a}$ & $56.9 \mathrm{a}$ & $51.2 \mathrm{a}$ & & \\
\hline \multirow{3}{*}{ Fruit } & As- & 148.8 & 154.0 & 119.9 & 204.6 & 161.1 & 231.1 & $169.9 \mathrm{a}$ & 37.3 \\
\hline & As+ & 150.3 & 134.6 & 159.1 & 201.5 & 182.0 & 170.9 & 166.4 a & \\
\hline & Mean & $149.6 \mathrm{c}$ & $144.3 \mathrm{c}$ & $139.5 \mathrm{c}$ & $203.0 \mathrm{a}$ & $171.5 \mathrm{~b}$ & 201.0 a & & \\
\hline
\end{tabular}

\subsection{Leaf Growth Variables}

All leaf growth variables were significantly affected by the 'As concentration $\times$ rootstock' interaction (Table 2). With the As increase in the nutrient solution, both $\mathrm{L}_{\mathrm{N}}$ and $\mathrm{L}_{\mathrm{A}}$ showed the strongest reduction in the grafting combinations "Proteo"/“"Dinero" ( -43 leaves plant ${ }^{-1}$ and $-34.4 \mathrm{dm}^{2}$ plant $^{-1}$, respectively), "Proteo"//"Magnus" (-42 leaves plant ${ }^{-1}$ and $-27.2 \mathrm{dm}^{2}$ plant $^{-1}$ ), and "Proteo"/'Strong Tosa' (-27 leaves plant $^{-1}$ and $-19.3 \mathrm{dm}^{2}$ plant $^{-1}$ ) (Table 2). Similarly, LAR and LWR showed a significant reduction passing from As- to As+ solution, with the strongest drops recorded in the grafting combinations "Proteo"/"Dinero" $\left(-7.6 \mathrm{~cm}^{2} \mathrm{~g}^{-1} \mathrm{DW}\right.$ and $-0.054 \mathrm{~g} \mathrm{~g}^{-1} \mathrm{DW}$, respectively) and "Proteo"/“Magnus" $\left(-16 \mathrm{~cm}^{2} \mathrm{~g}^{-1} \mathrm{DW}\right.$ and $\left.-0.073 \mathrm{~g} \mathrm{~g}^{-1} \mathrm{DW}\right)$ (Table 2). 
Table 2. Leaf growth variables in melon plant as affected by As concentration in the nutrient solution and rootstock. Different letters within main factors indicate significance at Fisher's LSD test $(p=0.05)$.

\begin{tabular}{|c|c|c|c|c|c|c|c|c|c|}
\hline \multirow[b]{2}{*}{ Variabl } & & \multicolumn{6}{|c|}{ Rootstock } & \multirow[b]{2}{*}{ Mean } & \multirow{2}{*}{$\begin{array}{l}\text { LSD }_{\text {interaction }} \\
\quad(p=0.05)\end{array}$} \\
\hline & & $\begin{array}{l}\text { "Proteo" } \\
\text { (Control) }\end{array}$ & "Dinero" & "Magnus" & “RS841” & "Shintoza" & "Strong Tosa" & & \\
\hline \multirow{2}{*}{$\begin{array}{c}\mathrm{L}_{\mathrm{N}} \\
\text { (n. plant } \\
\text { (1) }\end{array}$} & As+ & 159 & 135 & 145 & 140 & 162 & 149 & $148 \mathrm{~b}$ & \\
\hline & Mean & 161 a & 156 a & 166 a & 149 a & 160 a & 162 a & & \\
\hline \multirow{2}{*}{$\begin{array}{c}\mathrm{L}_{\mathrm{A}} \\
\left(\mathrm{dm}^{2} \text { plant }^{-1}\right)\end{array}$} & As- & 74.1 & 91.5 & 86.9 & 75.9 & 83.6 & 86.3 & $83.1 \mathrm{a}$ & 14.5 \\
\hline & As+ & 66.9 & 57.1 & 59.7 & 63.3 & 83.3 & 67.0 & $66.2 \mathrm{~b}$ & \\
\hline \multirow{2}{*}{$\begin{array}{c}\text { LAR } \\
\left(\mathrm{cm}^{2} \mathrm{~g}^{-1} \mathrm{DW}\right)\end{array}$} & As+ & 30.7 & 28.8 & 26.4 & 22.7 & 31.5 & 28.3 & $28.1 \mathrm{~b}$ & \\
\hline & Mean & $31.2 \mathrm{ab}$ & $32.6 \mathrm{ab}$ & $34.4 \mathrm{a}$ & $24.0 \mathrm{c}$ & $32.8 \mathrm{a}$ & $27.7 \mathrm{bc}$ & & \\
\hline \multirow{3}{*}{$\begin{array}{c}\mathrm{LWR} \\
\left(\mathrm{g} \mathrm{g}^{-1} \mathrm{DW}\right)\end{array}$} & As- & 0.243 & 0.267 & 0.270 & 0.223 & 0.230 & 0.183 & $0.236 \mathrm{a}$ & 0.034 \\
\hline & As+ & 0.217 & 0.213 & 0.197 & 0.190 & 0.217 & 0.187 & $0.203 \mathrm{~b}$ & \\
\hline & Mean & $0.230 \mathrm{ab}$ & $0.240 \mathrm{a}$ & $0.233 \mathrm{a}$ & $0.207 a b$ & $0.223 b c$ & $0.185 c$ & & \\
\hline
\end{tabular}

\subsection{Leaf Relative Chl Content and Gas Exchanges}

Leaf relative $\mathrm{Chl}$ content did not differ in relation to rootstock, while in all grafting combinations it increased by 7\% (from 55.3 to 59.3 SPAD units) in the As+ solution (Table 3). The highest $A_{N}$ values in As- solution were recorded in "Proteo" grafted onto "Magnus", "RS841", and 'Strong Tosa' (27.4 $\mu \mathrm{mol} \mathrm{CO} \mathrm{CO}^{-2} \mathrm{~s}^{-1}$, on average). Nevertheless under As+ treatment, the grafting combination "Proteo"|"RS841" showed a significant $A_{N}$ reduction (from 27.7 to $22.7 \mu \mathrm{mol} \mathrm{CO} \mathrm{Cm}^{-2} \mathrm{~s}^{-1},-18 \%$ ), whereas an opposite trend was recorded in self-grafted "Proteo" (from 25.3 to $27.7 \mu \mathrm{mol} \mathrm{CO} \mathrm{m}^{-2} \mathrm{~s}^{-1}$, $+10 \%$ ) (Table 3). Passing from As- to Ast, gs significantly varied in the grafting combinations "Proteo"/"Dinero" (from 273 to $385 \mu \mathrm{mol} \mathrm{CO} \mathrm{m}^{-2} \mathrm{~s}^{-1},+41 \%$ ), "Proteo"/"Shintoza" (from 190 to $245 \mu \mathrm{mol} \mathrm{CO} \mathrm{m}^{-2} \mathrm{~s}^{-1},+29 \%$ ), and "Proteo"/“Magnus" (from 275 to $207 \mu \mathrm{mol} \mathrm{CO} \mathrm{m}^{-2} \mathrm{~s}^{-1},-25 \%$ ), with the control showing stable gs values across nutrient solutions (Table 3). "RS841" rootstock maximized the WUE values in As-, but showed the highest decrease in response to As+ (being reduced from 3.5 to $3.0 \mu \mathrm{mol} \mathrm{CO} \mu_{2} \mathrm{~mol}^{-1} \mathrm{H}_{2} \mathrm{O} \mathrm{m}^{-2} \mathrm{~s}^{-1},-12 \%$ ), while an opposite trend was recorded in self-grafted "Proteo" (from 3.0 to $3.4 \mu \mathrm{mol} \mathrm{CO} \mu_{2} \mu \mathrm{mol}^{-1} \mathrm{H}_{2} \mathrm{O} \mathrm{m}^{-2} \mathrm{~s}^{-1},+14 \%$ ). A similar response was recorded when "Proteo" was grafted onto 'Strong Tosa' (from 2.8 to $3.3 \mu \mathrm{mol} \mathrm{CO}{ }_{2} \mu \mathrm{mol}^{-1} \mathrm{H}_{2} \mathrm{O}$ $\mathrm{m}^{-2} \mathrm{~s}^{-1},+17 \%$ ) and "Magnus" (from 2.8 to $3.6 \mu \mathrm{mol} \mathrm{CO} 2 \mu \mathrm{mol}^{-1} \mathrm{H}_{2} \mathrm{O} \mathrm{m}^{-2} \mathrm{~s}^{-1},+26 \%$ ) (Table 3).

Table 3. Leaf relative Chl content and gas exchange variables in melon plant as affected by As concentration in the nutrient solution and rootstock. Different letters within main factors indicate significance at Fisher's LSD test $(p=0.05)$. NS—not significant.

\begin{tabular}{|c|c|c|c|c|c|c|c|c|c|}
\hline \multirow[b]{2}{*}{ Variable } & & \multicolumn{6}{|c|}{ Rootstock } & \multirow[b]{2}{*}{ Mean } & \multirow{2}{*}{$\begin{array}{c}\text { LSD }_{\text {interaction }} \\
(p=0.05)\end{array}$} \\
\hline & & $\begin{array}{l}\text { "Proteo" } \\
\text { (Control) }\end{array}$ & "Dinero" & "Magnus" & "RS841" & "Shintoza" & "Strong Tosa" & & \\
\hline \multirow{3}{*}{ SPAD } & As- & 55.7 & 56.4 & 54.7 & 56.1 & 52.9 & 55.9 & $55.3 \mathrm{~b}$ & NS \\
\hline & As+ & 57.5 & 59.3 & 58.1 & 61.7 & 58.6 & 60.8 & $59.3 \mathrm{a}$ & \\
\hline & Mean & $56.6 \mathrm{a}$ & $57.8 \mathrm{a}$ & $56.4 \mathrm{a}$ & $58.9 \mathrm{a}$ & 55.7 a & $58.4 \mathrm{a}$ & & \\
\hline \multirow{3}{*}{$\begin{array}{c}\mathrm{A}_{\mathrm{N}} \\
\left(\mu \mathrm{mol} \mathrm{CO} \mathrm{m}^{-2} \mathrm{~s}^{-1}\right)\end{array}$} & As- & 25.3 & 25.0 & 26.7 & 27.7 & 25.1 & 27.7 & $26.2 \mathrm{a}$ & 2.2 \\
\hline & As+ & 27.7 & 23.2 & 25.6 & 22.7 & 25.4 & 29.1 & $25.6 \mathrm{a}$ & \\
\hline & Mean & $26.5 \mathrm{~b}$ & $24.1 \mathrm{c}$ & $26.1 \mathrm{~b}$ & $25.2 \mathrm{bc}$ & $25.2 \mathrm{bc}$ & $28.4 \mathrm{a}$ & & \\
\hline \multirow{3}{*}{$\begin{array}{c}\text { Gs } \\
\left(\mu \mathrm{mol} \mathrm{CO} \mathrm{m}^{-2} \mathrm{~s}^{-1}\right)\end{array}$} & As- & 240 & 273 & 275 & 255 & 190 & 330 & 261 a & 43 \\
\hline & As+ & 247 & 385 & 207 & 230 & 245 & 300 & $269 a$ & \\
\hline & Mean & $243 b$ & $329 a$ & $241 \mathrm{~b}$ & $243 b$ & $218 b$ & 315 a & & \\
\hline WUE & As- & 3.0 & 3.0 & 2.8 & 3.5 & 3.0 & 2.8 & $3.0 \mathrm{~b}$ & 0.3 \\
\hline$\left(\mu \mathrm{mol} \mathrm{CO} 2 \mu \mathrm{mol}^{-1}\right.$ & As+ & 3.4 & 2.8 & 3.6 & 3.0 & 3.2 & 3.3 & $3.2 \mathrm{a}$ & \\
\hline $\left.\mathrm{H}_{2} \mathrm{O} \mathrm{m}^{-2} \mathrm{~s}^{-1}\right)$ & Mean & $3.2 \mathrm{a}$ & $2.9 \mathrm{~b}$ & $3.2 \mathrm{a}$ & $3.3 \mathrm{a}$ & $3.1 \mathrm{ab}$ & $3.1 \mathrm{ab}$ & & \\
\hline
\end{tabular}

$\mathrm{A}_{\mathrm{N}}$-net assimilation rate; gs—stomatal conductance; WUE-water use efficiency. 


\subsection{Arsenic Accumulation in Plant Fractions}

Arsenic accumulation in plant fractions was significantly affected by the main factors and their interaction (Table 4). In As- treatment, the highest As root was recorded in the rootstocks "Magnus" and "Proteo" (11.75 $\mathrm{mg} \mathrm{kg} \mathrm{DW}^{-1}$, on average), while the lowest one in "RS841" (6.26 $\left.\mathrm{mg} \mathrm{kg} \mathrm{DW}^{-1}\right)$. In the As+ treatment, As root increased in all the tested rootstocks, with the highest concentration recorded in "Magnus" (1633.57 mg kg-1 DW, +131 fold than control), while the lowest one in "RS841" (369.10 $\mathrm{mg} \mathrm{kg}^{-1} \mathrm{DW},+58$ fold) (Table 4). The As+ treatment promoted As shoot in a rootstock-dependent way too, since passing from As- to As+, "RS841" showed the highest As shoot increase (by $25.61 \mathrm{mg} \mathrm{kg}^{-1}$ $\mathrm{DW},+43$ fold than control), whereas 'Strong Tosa' showed the least one (by $21.75 \mathrm{mg} \mathrm{kg}^{-1} \mathrm{DW},+36$ fold) (Table 4). By increasing the As concentration in the nutrient solution, Aspulp increased in all the grafting combinations, with the highest rise recorded in "Proteo" grafted onto "Shintoza" and "Dinero" (by $3.09 \mathrm{mg} \mathrm{kg}^{-1} \mathrm{DW}$, on average, equal to +14 fold than control) and the least one recorded in self-grafted "Proteo" (by $1.86 \mathrm{mg} \mathrm{kg}^{-1} \mathrm{DW},+2$ fold) (Table 4).

Table 4. Total arsenic accumulation $\left(\mathrm{mg} \mathrm{kg}^{-1} \mathrm{DW}\right)$ in different organs of melon plant as affected by As concentration in the nutrient solution and rootstock. Different letters within main factors indicate significance at Fisher's LSD test $(p=0.05)$.

\begin{tabular}{|c|c|c|c|c|c|c|c|c|c|}
\hline & & \multicolumn{6}{|c|}{ Rootstock } & \multirow[b]{2}{*}{ Mean } & \multirow{2}{*}{$\begin{array}{l}\text { LSD }_{\text {interaction }} \\
\quad(p=0.05)\end{array}$} \\
\hline \multicolumn{2}{|c|}{ Variable } & $\begin{array}{l}\text { "Proteo" } \\
\text { (Control) }\end{array}$ & "Dinero" & "Magnus" & “RS841" & "Shintoza" & "Strong Tosa" & & \\
\hline \multirow{3}{*}{ As root } & As- & 11.84 & 7.10 & 11.65 & 6.26 & 8.09 & 8.35 & $8.88 \mathrm{~b}$ & 77.33 \\
\hline & As+ & 1031.53 & 1090.73 & 1633.57 & 369.10 & 732.75 & 805.88 & 943.93 a & \\
\hline & Mean & $521.68 \mathrm{~b}$ & $548.91 \mathrm{~b}$ & 822.61 a & $187.68 \mathrm{~d}$ & $370.42 \mathrm{c}$ & 407.12 c & & \\
\hline \multirow{3}{*}{$\mathrm{As}_{\text {shoot }}$} & As- & 0.71 & 0.86 & 0.77 & 0.59 & 0.47 & 0.60 & $0.67 \mathrm{~b}$ & 1.73 \\
\hline & As+ & 23.71 & 25.50 & 23.81 & 26.20 & 23.90 & 22.35 & $24.24 \mathrm{a}$ & \\
\hline & Mean & $12.21 \mathrm{ab}$ & 13.18 a & $12.29 \mathrm{ab}$ & $13.39 \mathrm{a}$ & $12.18 \mathrm{ab}$ & $11.48 \mathrm{~b}$ & & \\
\hline \multirow{3}{*}{$\mathrm{As}_{\text {pulp }}$} & As- & 0.86 & 0.14 & 0.46 & 0.29 & 0.30 & 0.60 & $0.44 \mathrm{~b}$ & 0.25 \\
\hline & As+ & 2.72 & 3.16 & 2.99 & 2.98 & 3.46 & 3.19 & $3.08 \mathrm{a}$ & \\
\hline & Mean & $1.79 \mathrm{ab}$ & $1.65 \mathrm{~b}$ & $1.72 \mathrm{ab}$ & $1.64 \mathrm{~b}$ & $1.88 \mathrm{a}$ & $1.89 \mathrm{a}$ & & \\
\hline
\end{tabular}

\subsection{Arsenic Speciation in Root}

Arsenic speciation in root was significantly affected by 'As concentration $\times$ rootstock' interaction (Table 5). In As- treatment, As snorganic in root accounted from 40.1\% ("Shintoza") to $60.1 \%$ ("Proteo"); however, in the As+ solution, this variable significantly decreased in the intraspecific rootstocks, namely "Proteo", "Dinero", and "Magnus" (-14.57\%, on average), while it increased in the interspecific hybrids "RS841", "Shintoza", and 'Strong Tosa' (+34.93\%, on average) (Table 5). In As- treatment,

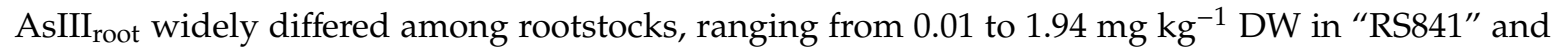
"Proteo", respectively. In the As+ treatment it showed the highest rise in 'Strong Tosa' (+577.24 mg $\mathrm{kg}^{-1}$ DW; i.e., +3207 fold than control) and "Shintoza" ( $+287.39 \mathrm{mg} \mathrm{kg}^{-1}$ DW; i.e., +3193 fold), and the least one in "RS841" (+82.25 mg kg-1 DW; i.e., +8225 fold) (Table 5). In As- treatment, AsV $\mathrm{V}_{\text {root }}$ showed the highest value in "Proteo" $\left(5.17 \mathrm{mg} \mathrm{kg}^{-1} \mathrm{DW}\right)$ and the least one in "Dinero" and "RS841" (2.88 $\mathrm{mg} \mathrm{kg}^{-1} \mathrm{DW}$, on average) (Table 5). When plants were grown in the As+ solution, such variable showed the highest increase in "Magnus" (by $345.94 \mathrm{mg} \mathrm{kg}^{-1} \mathrm{DW}$; i.e., +80 fold than control), followed by "Proteo" and "Dinero" (by $255.88 \mathrm{mg} \mathrm{kg}^{-1} \mathrm{DW}$, on average; i.e., +64 fold), and the least one in 'Strong Tosa' (by $41.85 \mathrm{mg} \mathrm{kg}^{-1} \mathrm{DW}$; i.e., +14 fold) (Table 5). 
Table 5. Inorganic As (percentage of total), $\mathrm{As}(\mathrm{III})$, and $\mathrm{As}(\mathrm{V})\left(\mathrm{mg} \mathrm{kg}^{-1} \mathrm{DW}\right)$ in root of melon plant as affected by As concentration in the nutrient solution and rootstock. Different letters within main factors indicate significance at Fisher's LSD test $(p=0.05)$.

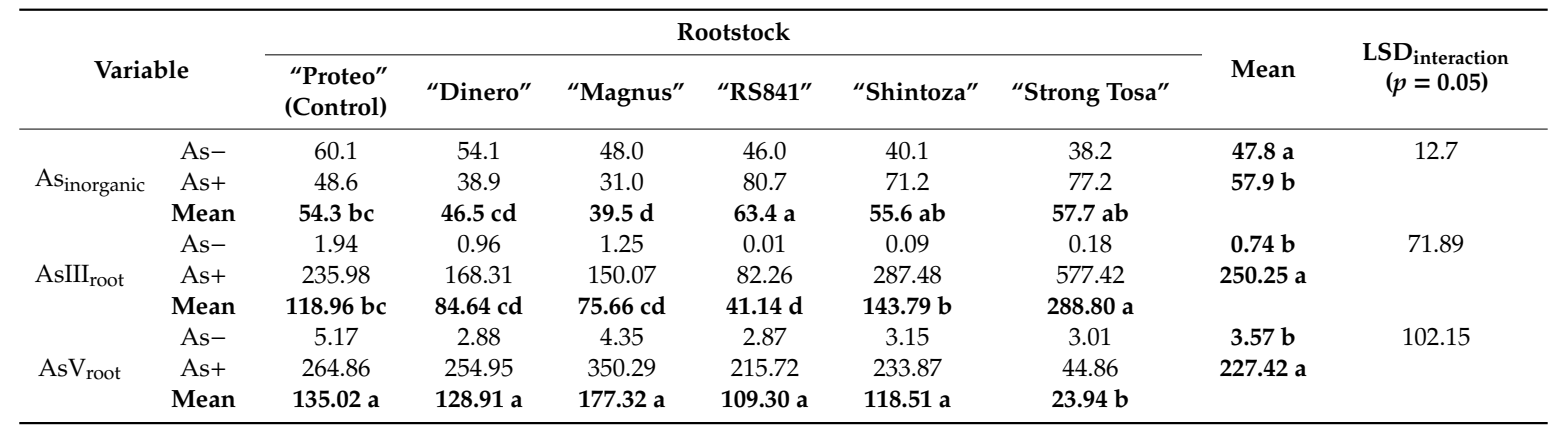

\subsection{Arsenic Bioaccumulation and Translocation Factors}

All the bioaccumulation and translocation factors proved to be higher under the control growing conditions, displaying a sharp decrease in response to the As+ treatment (Table 6). Shifting from

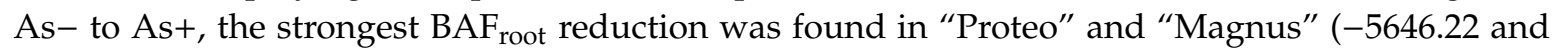
-5394.68 , respectively, corresponding to $-95 \%$ and $-93 \%$ ), while the least one in "Dinero" and "RS841" (-3260.82 and -3033.38 , respectively, corresponding to $-92 \%$ and $-97 \%$ ) (Table 6). Differently, "Dinero" caused the sharper $\mathrm{BAF}_{\text {shoot }}$ decrease in response to As+ treatment $(-422.82$, i.e., $-98 \%)$, followed by "Magnus" (-377.37, i.e., $-98 \%)$, while "Shintoza" generated the smallest variation (-229.6, i.e., -97\%) (Table 6). With reference to BAF pulp, "Proteo" and "Strong Tosa" generated the strongest drop in response to As+ (by -426.92 and -298.47 , respectively, corresponding to $-99.8 \%$ and $-99.7 \%$ ), whereas a less marked decrease was recorded when "Proteo" was grafted onto "Shintoza" (-150.45, i.e., $-99.4 \%)$, "RS841" (-145.92; i.e., $-99.5 \%)$ and "Dinero" (-68.05, i.e.; $-98.8 \%)$ (Table 6). The increase in As concentration in the root environment caused the highest $\mathrm{TF}_{\text {shoot }}$ reductions in "Proteo" grafted onto "Dinero" (-0.097; i.e., $-80.2 \%)$ and "Magnus" (-0.051, i.e., $-77.3 \%)$, while the least ones in the grafting combinations "Proteo"/"Shintoza" (-0.025; i.e., $-43.1 \%)$ and "Proteo"/“RS841" (-0.024; i.e., $-25.3 \%$ ) (Table 6). "Strong Tosa", "Magnus" and "Shintoza" proved the highest TF pulp reduction in response to the As stress $(-0.069,-0.038$, and -0.032 , respectively, corresponding to $-94.5 \%,-95.0 \%$, and $-86.5 \%)$, whereas "Dinero" showed the least one $(-0.007$; i.e., $-84.2 \%)$ (Table 6$)$.

Table 6. Arsenic bioaccumulation and translocation factors (adimensional) in shoot and pulp of melon plants as affected by As concentration in the nutrient solution and rootstock. Different letters within main factors indicate significance at Fisher's LSD test $(p=0.05)$.

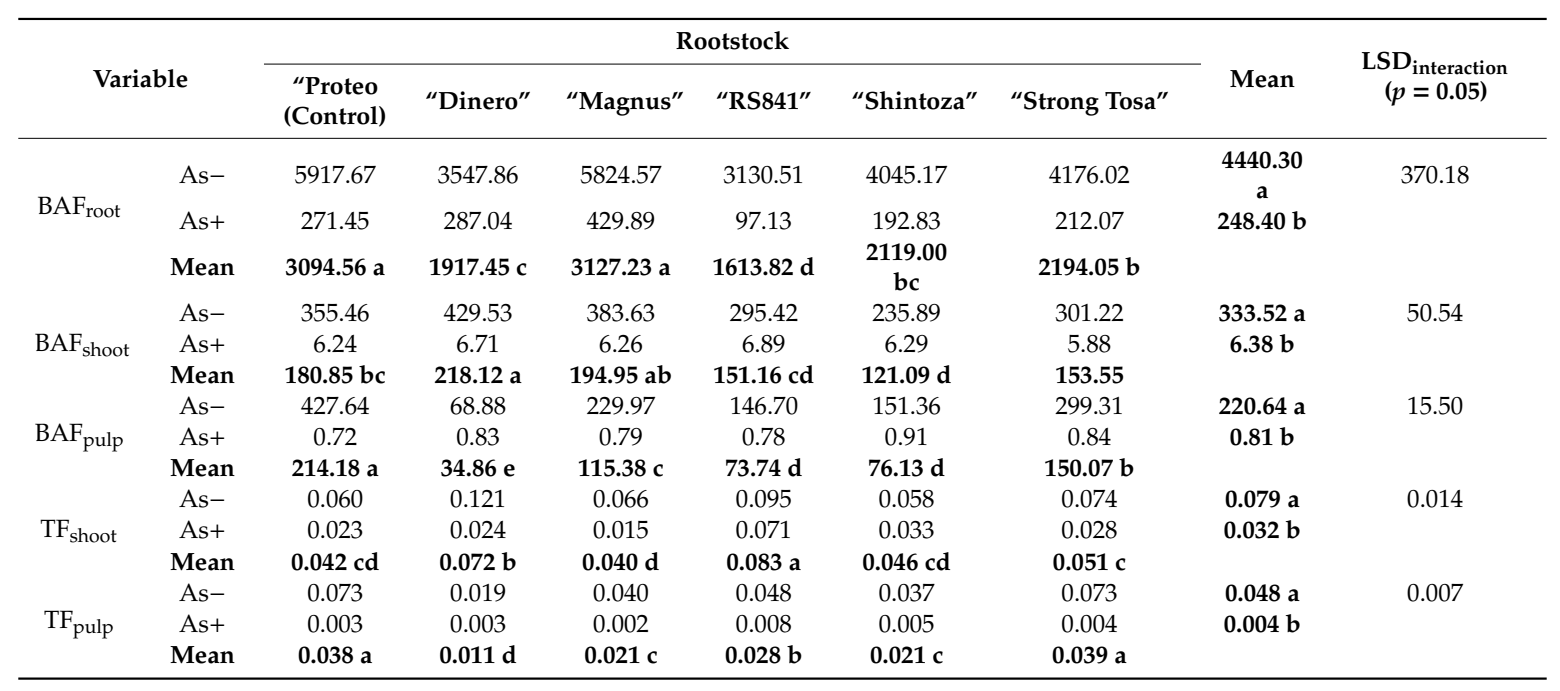




\subsection{Phosphorus Accumulation in Plant Fractions}

Phosphorus accumulation in plant fractions was significantly affected by the main factors and their interaction (Table 7). Passing from As- to As+ treatment, $\mathrm{P}_{\text {root }}$ increased mostly in self-grafted "Proteo" (from 3527 to 31,390 mg kg-1 DW, +790\%), followed by "Dinero" (from 3566 to 17,059 mg $\mathrm{kg}^{-1} \mathrm{DW},+378 \%$ ), "Magnus" (from 14,362 to 22,938 $\mathrm{mg} \mathrm{kg}^{-1} \mathrm{DW},+60 \%$ ), and "Shintoza" (from 12,535 to $19,210 \mathrm{mg} \mathrm{kg}^{-1} \mathrm{DW},+53 \%$ ) (Table 7). Conversely, the As+ treatment significantly reduced $\mathrm{P}_{\text {shoot }}$ as compared to the standard nutrient solution, with the highest drop recorded in "Proteo" grafted onto "Dinero" and "Magnus" (from 7001 to $4923 \mathrm{mg} \mathrm{kg}^{-1} \mathrm{DW}$, on average, -30\%) (Table 7). Passing from As- to As+, $P_{\text {pulp }}$ significantly increased in "Proteo" grafted onto "Dinero", "Magnus", and 'Strong Tosa' (by 4472, 1334, and $1203 \mathrm{mg} \mathrm{kg}^{-1} \mathrm{DW}$, respectively, corresponding to $+758 \%$, $+35 \%$, and $+30 \%$ ), whereas did not show any significant variation in the other graft combinations (Table 7).

Table 7. Phosphorus accumulation $\left(\mathrm{mg} \mathrm{kg}^{-1} \mathrm{DW}\right)$ in different organs of melon plants as affected by As concentration in the nutrient solution and rootstock. Different letters within main factors indicate significance at Fisher's LSD test $(p=0.05)$.

\begin{tabular}{|c|c|c|c|c|c|c|c|c|c|}
\hline \multirow{2}{*}{\multicolumn{2}{|c|}{ Variable }} & \multicolumn{6}{|c|}{ Rootstock } & \multirow[b]{2}{*}{ Mean } & \multirow{2}{*}{$\begin{array}{l}\text { LSD }_{\text {interaction }} \\
\quad(p=0.05)\end{array}$} \\
\hline & & $\begin{array}{l}\text { "Proteo" } \\
\text { (Control) }\end{array}$ & "Dinero" & "Magnus" & “RS841" & "Shintoza" & "Strong Tosa" & & \\
\hline \multirow{3}{*}{$P_{\text {root }}$} & As- & 3527 & 3566 & 14362 & 12959 & 12535 & 20875 & $11304 \mathrm{~b}$ & 3111 \\
\hline & Ast & 31390 & 17059 & 22938 & 10379 & 19210 & 22343 & 20553 a & \\
\hline & Mean & 17458 bc & $10312 \mathrm{~d}$ & $18650 \mathrm{~b}$ & $11669 \mathrm{~d}$ & 15872 c & 21609 a & & \\
\hline \multirow{3}{*}{$P_{\text {shoot }}$} & As- & 7038 & 7131 & 6871 & 6039 & 6465 & 6538 & $6681 a$ & 564 \\
\hline & As+ & 6434 & 5064 & 4782 & 5563 & 5861 & 5786 & $5582 \mathrm{~b}$ & \\
\hline & Mean & $6736 a$ & $6098 \mathrm{~b}$ & $5827 \mathrm{~b}$ & $5801 \mathrm{~b}$ & $6163 b$ & $6162 b$ & & \\
\hline \multirow{3}{*}{$P_{\text {pulp }}$} & As- & 4745 & 590 & 3827 & 4119 & 4110 & 3996 & $3565 \mathrm{~b}$ & 521 \\
\hline & As+ & 5151 & 5062 & 5161 & 3797 & 4561 & 5199 & 4822 a & \\
\hline & Mean & 4948 a & $2826 \mathrm{~d}$ & $4494 \mathrm{~b}$ & $3958 \mathrm{c}$ & $4335 \mathrm{~b}$ & $4597 \mathrm{ab}$ & & \\
\hline
\end{tabular}

\subsection{Principal Component Analysis}

The first two principal components gave eigenvalues equal to 2.75 (PC1) and 0.21 (PC2), and together accounted for $98.9 \%$ of the total variance (Table 8 ). The As accumulation into the different plant fractions positively contributed to PC1, with correlation coefficient ranging from 0.556 to 0.589 , while PC2 was strongly and positively correlated to As root (0.830) and negatively correlated to As shoot and $\mathrm{As}_{\text {pulp }}$ (-0.367 and -0.419 , respectively). The resulting PCA scatterplot showed a clear separation among plants grown in As- (on the negative side of PC1) and those grown in As+ (on the right side of PC1). The first group clustered together, with no separation between different plant organs, while the second group showed a further separation in two sub-clusters, in the second and fourth quadrant of the centroid, respectively (Figure 1). The first sub-cluster grouped on the positive side of PC2 the grafting combinations (self-grafted "Proteo", "Proteo"/"Magnus", and "Proteo"/"Dinero") accumulating As mainly in root, while the second sub-cluster grouped those combinations ("Proteo"/'Strong Tosa', "Proteo"/"Shintoza", and "Proteo"/“RS841"), accumulating As in the aerial parts of the plant, namely shoot and pulp (Figure 1).

Table 8. Correlation coefficients for each trait with respect to the first two principal components, eigenvalues, and relative and cumulative proportions of the explained variance.

\begin{tabular}{ccc}
\hline Trait & \multicolumn{2}{c}{ Principal Component Coefficients } \\
\cline { 2 - 3 } & First & Second \\
\hline As soot & 0.556 & 0.830 \\
As shoot $_{\text {Asulp }}$ & 0.589 & -0.367 \\
Eigenvalue & 0.586 & -0.419 \\
Explained Variability $(\%)$ & 2.75 & 0.21 \\
& 91.91 & 7.07 \\
\hline
\end{tabular}




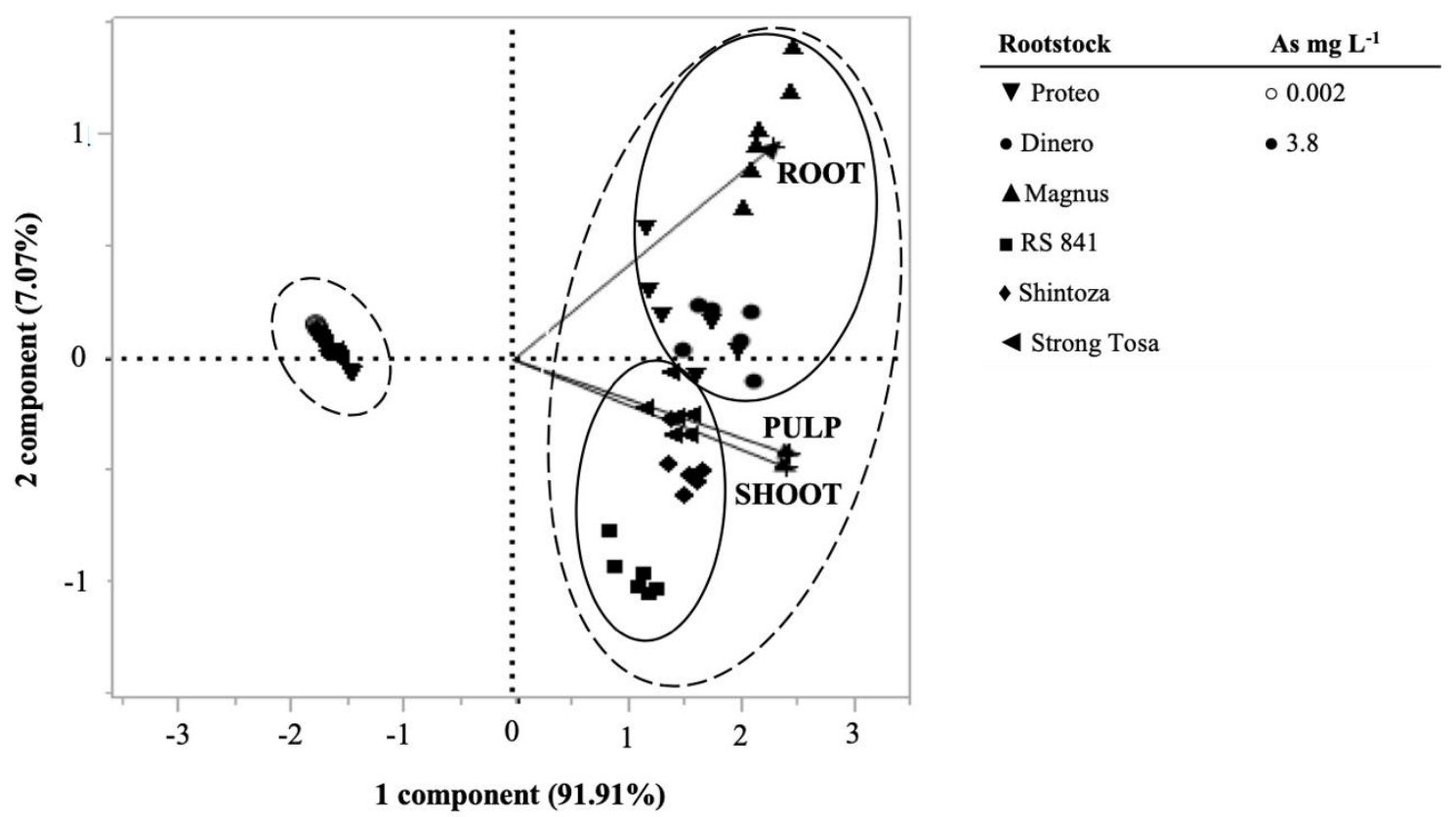

Figure 1. Principal Component Analysis scatter-plot based on total As concentration in root, shoot and pulp of melon plant "Proteo" as a function of the grafting combination and As concentration of the nutrient solution. Dotted lines group together treatments at different concentrations of As in the nutrient solution, while solid lines group together the grafting combinations.

\section{Discussion}

The environmental As contamination is a worldwide health threat due to the toxic and carcinogenic nature of this metalloid [29]. From an agricultural viewpoint, plants exposure to As- stress can cause morphological, physiological, and biochemical changes, leading to altered photosynthesis, stunted growth, reduced crop productivity, and worsened toxicological profile of the edible fractions [30]. In our experiment, the bioaccumulation factors values revealed that, even at a low As concentration in the nutrient solution, melon behaves as an hyperaccumulator plant, following the gradient root $>$ shoot $>$ fruit generally reported in literature [31]. However, when exposed to an As+ solution, all the grafting combinations acted to limit the As entrance into the plant, as can be inferred from the average reduction of $\mathrm{BAF}_{\text {root }}(-94.4 \%), \mathrm{BAF}_{\text {shoot }}(-98.1 \%)$, and $\mathrm{BAF}_{\text {pulp }}(-99.6 \%)$. Nonetheless plants exposure to As stress highlighted evidences of systemic stress, consisting in a decrease of the whole aboveground dry biomass per plant, which mainly mirrored the reduction of both, stem and leaf dry biomass per plant. The reduced plant growth in response to As toxicity originates from complex alterations involving enzymes activity, induction of oxidative stresses, or altered nutrient uptake and balance into the plant [32,33]. In the present experiment melon plants subjected to As stress showed a decreased ability to maintain the normal growth equilibrium among plant fractions, by partially losing $(\sim 20 \%)$ the ability of photosynthates investment into leaf biomass, so indicating the main photosynthetic organs as an elective target of As-induced alterations. Leaf area, leaf area ratio, and leaf weight ratio were predominantly affected by the As toxicity, more than leaf number, indicating leaf cells proliferation and elongation as primarily affected by the As stress, more than leaf cells differentiation. According to Koyama and Kikuzawa [34] and Ropokis et al. [35], leaf area is a trait having a central role in determining the level of nutrient uptake, via the rate of whole plant photosynthesis and transpiration. In this sense, the decreased leaf area we recorded suggests the triggering of morpho-physiological modifications reducing the As entrance inside the plant, probably by modulating the plant's transpiration and nutrient demand.

Regarding photosynthesis, As accumulation in leaf tissues is responsible for key physiological events such as chlorophyll degradation and leaf necrosis, decreased activity of the enzymes involved 
in photosynthetic metabolism, disturbance of photosynthates transport, and stomatal behavior [36,37]. This, apparently, was not reflected in our experiment where, besides the absence of any leaf necrosis (data not shown), there was a general increase in leaf relative chlorophyll content, as can be inferred from SPAD readings. This result is consistent with those of $\mathrm{Zu}$ et al. [37], which have reported that As is able to promote chlorophyll content in leaf tissues, becoming harmful only above a threshold concentration.

The analysis of net photosynthetic rate revealed different degrees of sensibility to the As toxicity among grafting combinations, with self-grafted "Proteo" experiencing a slight stimulation under As stress, a feature opposite to that displayed by "Proteo"-"RS841" combination. Both trends were associated to correspondingly similar patterns of water use efficiency, but not to any correlated change in stomatal conductance, indicating that mechanisms beyond stomatal behavior are involved in determining the photosynthetic response of As-stressed melon plants. Interestingly, under severe As stress, the $A_{N}$ variations induced by the different rootstocks were not correlated to any corresponding variation of the aboveground biomass per plant, so that $A_{N}$ and plant growth were apparently not related to each other. Indeed, under As+ treatment, both whole plant and fruit biomass resulted generally higher in "Proteo" grafted onto the C. maxima $\times$ C. moschata hybrids (namely "RS841", "Shintoza" and "Strong Tosa"; i.e., those rootstocks conferring no $A_{N}$ enhancement under As-enriched nutrient solution). This seems to suggest a differential alteration of the energy balance of the plants, likely attributable to different energy dissipation pathways involved in the As stress response [38]. The data of As speciation and partitioning we found seem to confirm such hypothesis. Indeed, when exposed to the As+ treatment, the intraspecific rootstocks showed the highest total As concentration in roots, but the lowest one under its inorganic form (from 31\% to $49 \%$ ), meaning that up to $69 \%$ of their $\mathrm{As}_{\text {root }}$ was present in organic and complexed form. This is the As form whose translocation from root is hampered, because of bonds with thiol groups of root-synthetized phytochelatins and subsequent sequestration into root cells vacuole [39]. On the contrary, the interspecific rootstocks subjected to the As+ treatment, showed the lowest total As concentration in their root, demonstrating their superior ability to buffer the As entrance into the plant from the nutrient solution. However, they showed also the highest inorganic $\mathrm{As}_{\text {root }}$ incidence (up to $81 \%$; i.e., the most mobile As form from the root organ) $[39,40]$. Inorganic As(III) is the main species suitable for transport trough xylem vessels and/or root efflux, while $\mathrm{As}(\mathrm{V})$ is rapidly reduced in roots to $\mathrm{As}(\mathrm{III})$ and then transported from the root cortical cells to the xylem vessels $[40,41]$. Accordingly, when growing under conditions of As stress, all the interspecific rootstocks had the highest $\mathrm{TF}_{\text {shoot }}$ and $\mathrm{TF}_{\text {pulp }}$ values, with "Shintoza" and "Strong Tosa" having also the highest concentration of As(III) in their roots. On the contrary, "Magnus" and "Dinero" confirmed the lowest $\mathrm{TF}_{\text {shoot }}$ and $\mathrm{TF}_{\text {pulp }}$ values, respectively, since the highest incidence of organic As into their roots.

Several authors have reported that the As uptake and translocation kinetics are mainly dependent on its concentration in the root environment and plant species [42,43], with the diversity of the root systems having a central role in determining differences among genotypes [44]. The PCA scatter plot highlighted that the As concentration in the root environment had a pivotal role in triggering different behaviors among rootstocks. Indeed, when exposed to the standard nutrient solution, all the grafting combinations clustered together on the negative side of PC1 (indicating lower values of As accumulation in plant tissues), without differences in terms of As partitioning inside the plant fractions. The opposite was noticed under conditions of imposed As stress, so that the grafting combinations clustered on the positive side of PC1, with a further distinction along the PC2 between rootstocks promoting the As accumulation mainly in roots (i.e., the intraspecific rootstocks) and those promoting its accumulation in shoot and pulp, namely "Shintoza" and "Strong Tosa". "RS841" slightly diverged from these latter owing to its ability to contain the As accumulation into the pulp.

The present study took into account the uptake and translocation of $\mathrm{P}$ too, given its peculiar interaction with As, as well as for its role in improving the conversion of solar energy into new plant biomass [45]. The complex interrelation between arsenate and phosphate in the substrate-plant systems has brought, up to now, no univocal results in literature, since their interaction can be either 
synergistic or antagonistic, depending on the growing conditions [46]. In our experiment, both $P$ concentration and partitioning inside the plant were significantly modified by the As level in the nutrient solution, so that in As-stressed plants prevailed an increased P concentration in root and pulp, while a lowered one in shoot. This tendency was more marked when "Proteo" was grafted onto the intraspecific combinations. To this end, the protective role of $\mathrm{P}$ against the As-induced lipid peroxidation of cellular membranes has been suggested [47]. In this view, the selective increase in $P$ concentration inside the plant fractions could be the result of a melon response aimed at protecting both root (the plant organ firstly exposed to the As pollution) and reproductive structures from the As injury, this latter feature having been formerly described in rise [48]. On the other hand, the decreased $P$ concentration in shoot tissues seems well related to the decreased $L_{A}$, LAR, and LWR per plant recorded under conditions of As stress, so suggesting a possible role of P metabolism in buffering the transpiration-driven As entrance inside the plant.

\section{Conclusions}

The outcome of this experiment shows that As uptake and translocation into melon plants were both influenced by its concentration in the nutrient solution and by the genetic background of the rootstock. All tested plants, when grown in an As-enriched solution, showed a high As mobility in the substrate-plant continuum, resulting As accumulators most of all in root and shoot. Intraand interspecific rootstocks differently influenced the As $s_{\text {root }}$ accumulation inside the plant, with the interspecific hybrids proving a superior ability to limit the metalloid entrance into the roots. When subjected to As stress, melon plants acted to limit the metalloid translocation from root to shoot and pulp, so indicating the triggering of physiological mechanisms aimed at limiting the As diffusion inside the plant. To this end, the intraspecific rootstocks displayed a better ability to retain the toxic metalloid into the root system, most of all in an organic form. This feature suggests a higher efficiency of the root chelation mechanisms of As, occurring, in turn, at the expenses of the photosynthetic balance. The interspecific $C$. maxima $\times$ C. moschata rootstocks gave the best results in terms of fruit biomass under conditions of As stress, so suggesting the possibility to exploit their superior bio-agronomical potential with the aim to improve melon performances in heavily As-polluted areas. "RS841" proved to be the best rootstock in the view of maximizing yield and minimizing, at the same time, the As concentration into the fruit. Thus, the significant differences we found suggest the possibility to deepen this area of research, with the aim of identifying rootstocks genotypes for their superior agronomic and toxicological response to high As contamination in the root zone.

Author Contributions: C.L. and S.R.S. conceived the experiments and proposed the experimental design. F.G. and R.P.M. carried out the experiments. R.M. and E.A. carried out chemical experiments. R.P.M., A.E., S.R.S., R.M. interpreted data and wrote the manuscript. F.G. and A.I. critically revised the manuscript.

Funding: The research activity was co-funded by the Italian Ministry of University and Research (PRIN project "Health of agroecosystems: chemical, biochemical and biological processes that regulate the mobility of As in the soil-water-plant compartments" code 2010JBNLJ7_006).

Conflicts of Interest: The authors declare no conflict of interest. The funder had no role in the design of the study; in the collection, analyses, or interpretation of data; in the writing of the manuscript, or in the decision to publish the results.

\section{References}

1. Calatayud, Á.; San Bautista, A.; Pascual, B.; Maroto, J.V.; López-Galarza, S. Use of Chlorophyll Fluorescence Imaging as Diagnostic Technique to Predict Compatibility in Melon Graft. Sci. Hortic. (Amsterdam) 2013, 149, 13-18. [CrossRef]

2. Gupta, S.; Satpati, S.; Nayek, S.; Garai, D. Effect of Wastewater Irrigation on Vegetables in Relation to Bioaccumulation of Heavy Metals and Biochemical Changes. Environ. Monit. Assess. 2010, 165, 169-177. [CrossRef] [PubMed] 
3. Muchuweti, M.; Birkett, J.W.; Chinyanga, E.; Zvauya, R.; Scrimshaw, M.D.; Lester, J.N. Heavy Metal Content of Vegetables Irrigated with Mixtures of Wastewater and Sewage Sludge in Zimbabwe: Implications for Human Health. Agric. Ecosyst. Environ. 2006, 112, 41-48. [CrossRef]

4. Verkleij, J.A.C.; Golan-Goldhirsh, A.; Antosiewisz, D.M.; Schwitzguébel, J.P.; Schröder, P. Dualities in Plant Tolerance to Pollutants and Their Uptake and Translocation to the Upper Plant Parts. Environ. Exp. Bot. 2009, 67, 10-22. [CrossRef]

5. Meharg, A.A.; Macnair, M.R. Relationship between Plant Phosphorus Status and the Kinetics of Arsenate Influx in Clones of Deschampsia cespitosa (L.) Beauv. That Differ in Their Tolerance to Arsenate. Plant Soil 1994, 162, 99-106. [CrossRef]

6. Hughes, M.F.; Beck, B.D.; Chen, Y.; Lewis, A.S.; Thomas, D.J. Arsenic Exposure and Toxicology: A Historical Perspective. Toxicol. Sci. 2011, 123, 305-332. [CrossRef]

7. Carbonell-Barrachina, A.A.; Aarabi, M.A.; DeLaune, R.D.; Gambrell, R.P.; Patrick, W.H. The Influence of Arsenic Chemical Form and Concentration on Spartina Patens and Spartina Alterniflora Growth and Tissue Arsenic Concentration. Plant Soil 1998, 198, 33-43. [CrossRef]

8. Stazi, S.R.; Marabottini, R.; Papp, R.; Moscatelli, M.C. Arsenic in Soil: Availability and Interactions with Soil Microorganisms. In Heavy Metal Contamination of Soils; Sherameti, I., Varma, A., Eds.; Springer International Publishing: Cham, Switzerland, 2015; pp. 113-126. [CrossRef]

9. Garg, N.; Singla, P. Arsenic Toxicity in Crop Plants: Physiological Effects and Tolerance Mechanisms. Environ. Chem. Lett. 2011, 9, 303-321. [CrossRef]

10. Finnegan, P.M.; Chen, W. Arsenic Toxicity: The Effects on Plant Metabolism. Front. Physiol. 2012, 3, 1-18. [CrossRef]

11. Maurel, C.; Verdoucq, L.; Luu, D.T.; Santoni, V. Plant Aquaporins: Membrane Channels with Multiple Integrated Functions. Annu. Rev. Plant Biol. 2008, 59, 595-624. [CrossRef]

12. Allevato, E.; Stazi, S.R.; Marabottini, R.; D'Annibale, A. Mechanisms of arsenic assimilation by plants and countermeasures to attenuate its accumulation in crops other than rice. Ecotoxicol. Environ. Saf. 2019, 185, 109701. [CrossRef]

13. Abbas, G.; Murtaza, B.; Bibi, I.; Shahid, M.; Niazi, N.K.; Khan, M.I.; Amjad, M.; Hussain, M.; Natasha. Arsenic Uptake, Toxicity, Detoxification, and Speciation in Plants: Physiological, Biochemical, and Molecular Aspects. Int. J. Environ. Res. Public Health 2018, 15, 59. [CrossRef] [PubMed]

14. Verbruggen, N.; Hermans, C.; Schat, H. Mechanisms to Cope with Arsenic or Cadmium Excess in Plants. Curr. Opin. Plant Biol. 2009, 12, 364-372. [CrossRef] [PubMed]

15. Kyriacou, M.C.; Rouphael, Y.; Colla, G.; Zrenner, R.; Schwarz, D. Vegetable Grafting: The Implications of a Growing Agronomic Imperative for Vegetable Fruit Quality and Nutritive Value. Front. Plant Sci. 2017, 8, 1-23. [CrossRef]

16. Rouphael, Y.; Kyriacou, M.C.; Colla, G. Vegetable Grafting: A Toolbox for Securing Yield Stability under Multiple Stress Conditions. Front. Plant Sci. 2018, 8, 10-13. [CrossRef] [PubMed]

17. Sabatino, L.; Iapichino, G.; D’Anna, F.; Palazzolo, E.; Mennella, G.; Rotino, G.L. Hybrids and Allied Species as Potential Rootstocks for Eggplant: Effect of Grafting on Vigour, Yield and Overall Fruit Quality Traits. Sci. Hortic. Amsterdam 2018, 228, 81-90. [CrossRef]

18. Kumar, P.; Edelstein, M.; Cardarelli, M.; Ferri, E.; Colla, G. Grafting Affects Growth, Yield, Nutrient Uptake, and Partitioning under Cadmium Stress in Tomato. HortScience 2015, 50, 1654-1661. [CrossRef]

19. Stazi, S.R.; Cassaniti, C.; Marabottini, R.; Giuffrida, F.; Leonardi, C. Arsenic Uptake and Partitioning in Grafted Tomato Plants. Hortic. Environ. Biotechnol. 2016, 57, 241-247. [CrossRef]

20. Savvas, D.; Colla, G.; Rouphael, Y.; Schwarz, D. Amelioration of Heavy Metal and Nutrient Stress in Fruit Vegetables by Grafting. Sci. Hortic. 2010, 127, 156-161. [CrossRef]

21. Hoel, B.O.; Solhaug, K.A. Effect of irradiance on chlorophyll estimation with the Minolta SPAD-502 leaf chlorophyll meter. Ann. Bot. 1998, 82, 389-392. [CrossRef]

22. Martínez, D.E.; Guiamet, J.J. Distortion of the SPAD 502 chlorophyll meter readings by changes in irradiance and leaf water status. Agronomie 2004, 24, 41-46. [CrossRef]

23. Al-hamdani, S.H.; Murphy, J.M.; Todd, G.W. Stomatal conductance and $\mathrm{CO}_{2}$ assimilation as screening tools for drought resistance in sorghum. Can. J. Plant Sci. 1991, 71, 689-694. [CrossRef] 
24. Rintala, E.M.; Ekholm, P.; Koivisto, P.; Peltonen, K.; Venäläinen, E.R. The intake of inorganic arsenic from long grain rice and rice-based baby food in Finland-Low safety margin warrants follow up. Food Chem. 2014, 150, 199-205. [CrossRef] [PubMed]

25. Welna, M.; Pohl, P.; Szymczycha-Madeja, A. Non-chromatographic Speciation of Inorganic Arsenic in Rice by Hydride Generation Inductively Coupled Plasma Optical Emission Spectrometry. Food Anal. Methods 2019, 12, 581-594. [CrossRef]

26. Liu, J.; Zhang, X.H.; Li, T.Y.; Wu, Q.X.; Jin, Z.J. Soil characteristics and heavy metal accumulation by native plants in a Mn mining area of Guangxi, South China. Environ. Monit. Assess. 2014, 186, 2269-2279. [CrossRef]

27. de Campos, F.V.; de Oliveira, J.A.; da Silva, A.A.; Ribeiro, C.; dos Santos Farnese, F. Phytoremediation of arsenite-contaminated environments: Is Pistia stratiotes L. a useful tool? Ecol. Indic. 2019, 104, $794-801$. [CrossRef]

28. Pandey, J.; Verma, R.K.; Singh, S. Screening of most potential candidate among different lemongrass varieties for phytoremediation of tannery sludge contaminated sites. Int. J. Phytoremediat. 2019, 21, 600-609. [CrossRef]

29. Saldaña-Robles, A.; Abraham-Juárez, M.R.; Saldaña-Robles, A.L.; Saldaña-Robles, N.; Ozuna, C.; Gutiérrez-Chávez, A.J. The Negative Effect of Arsenic in Agriculture: Irrigation Water, Soil and Crops, State of the Art. Appl. Ecol. Environ. Res. 2018, 16, 1533-1551. [CrossRef]

30. Stazi, S.R.; Allevato, E.; Marabottini, R. Contaminazione Dei Prodotti Agricoli Da Arsenico: Assimilazione e Strategie Di Mitigazione. Italus Hortus 2016, 23, 19-32.

31. Ma, L.Q.; Komar, K.M.; Tu, C.; Zhang, W.; Cai, Y.; Kennelley, E.D. A Fern That Hyperaccumulates Arsenic. Nature 2001, 409, 579. [CrossRef]

32. Gomes, M.P.; Carvalho, M.; Carvalho, G.S.; Marques, T.C.L.L.S.M.; Garcia, Q.S.; Guilherme, L.R.G.; Soares, A.M. Phosphorus Improves Arsenic Phytoremediation by Anadenanthera peregrina by Alleviating Induced Oxidative Stress. Int. J. Phytoremediat. 2013, 15, 633-646. [CrossRef] [PubMed]

33. Mehmood, T.; Bibi, I.; Shahid, M.; Niazi, N.K.; Murtaza, B.; Wang, H.; Ok, Y.S.; Sarkar, B.; Javed, M.T.; Murtaza, G. Effect of Compost Addition on Arsenic Uptake, Morphological and Physiological Attributes of Maize Plants Grown in Contrasting Soils. J. Geochem. Explor. 2017, 178, 83-91. [CrossRef]

34. Koyama, K.; Kikuzawa, K. Is Whole-Plant Photosynthetic Rate Proportional to Leaf Area? A Test of Scalings and a Logistic Equation by Leaf Demography Census. Am. Nat. 2009, 173, 640-649. [CrossRef] [PubMed]

35. Ropokis, A.; Ntatsi, G.; Kittas, C.; Katsoulas, N.; Savvas, D. Impact of Cultivar and Grafting on Nutrient and Water Uptake by Sweet Pepper (Capsicum annuum L.) Grown Hydroponically Under Mediterranean Climatic Conditions. Front. Plant Sci. 2018, 9, 1-12. [CrossRef] [PubMed]

36. Rahman, A.M.; Hasegawa, H.; Mahfuzur Rahman, M.; Nazrul Islam, M.; Majid Miah, M.A.; Tasmen, A. Effect of Arsenic on Photosynthesis, Growth and Yield of Five Widely Cultivated Rice (Oryza sativa L.) Varieties in Bangladesh. Chemosphere 2007, 67, 1072-1079. [CrossRef]

37. Zu, Y.Q.; Sun, J.J.; He, Y.M.; Wu, J.; Feng, G.Q.; Li, Y. Effects of Arsenic on Growth, Photosynthesis and Some Antioxidant Parameters of Panax Notoginseng Growing in Shaded Conditions. Int. J. Adv. Agric. Res. 2016, 4, 78-88.

38. Srivastava, S.; Akkarakaran, J.J.; Sounderajan, S.; Shrivastava, M.; Suprasanna, P. Arsenic Toxicity in Rice (Oryza sativa L.) Is Influenced by Sulfur Supply: Impact on the Expression of Transporters and Thiol Metabolism. Geoderma 2016, 270, 33-42. [CrossRef]

39. Zhao, F.J.; Ma, J.F.; Meharg, A.A.; McGrath, S.P. Arsenic Uptake and Metabolism in Plants. New Phytol. 2009, 181, 777-794. [CrossRef]

40. Raab, A.; Schat, H.; Meharg, A.A.; Feldmann, J. Uptake, Translocation and Transformation of Arsenate and Arsenite in Sunflower (Helianthus annuus): Formation of Arsenic-Phytochelatin Complexes during Exposure to High Arsenic Concentrations. New Phytol. 2005, 168, 551-558. [CrossRef]

41. Pickering, I.J.; Prince, R.C.; George, M.J.; Smith, R.D.; George, G.N.; Salt, D.E. Reduction and Coordination of Arsenic in Indian Mustard 1. Plant Physiol. 2000, 122, 1171-1177. [CrossRef]

42. Ouyang, Y. Phytoextraction: Simulating Uptake and Translocation of Arsenic in a Soil-Plant System. Int. J. Phytoremediat. 2005, 7, 3-17. [CrossRef]

43. Wang, J.; Zhao, F.J.; Meharg, A.A.; Raab, A.; Feldmann, J.; McGrath, S.P. Mechanisms of Arsenic Hyperaccumulation in Pteris Vittata. Uptake Kinetics, Interactions with Phosphate, and Arsenic Speciation. Plant Physiol. 2002, 130, 1552-1561. [CrossRef] [PubMed] 
44. Chaturvedi, I. Effects of Arsenic Concentration and Forms on Growth and Arsenic Uptake and Accumulation by Indian Mustard (Brassica juncea L.) Genotyopes. J. Cent. Eur. Agric. 2006, 7, 31-40.

45. Ierna, A.; Mauro, R.P.; Mauromicale, G. Improved Yield and Nutrient Efficiency in Two Globe Artichoke Genotypes by Balancing Nitrogen and Phosphorus Supply. Agron. Sustain. Dev. 2012, 32, 773-780. [CrossRef]

46. Tu, C.; Ma, L.Q. Effects of Arsenate and Phosphate on Their Accumulation by an Arsenic-Hyperaccumulator Pteris vittata L. Plant Soil 2003, 249, 373-382. [CrossRef]

47. Gunes, A.; Pilbeam, D.J.; Inal, A. Effect of Arsenic-Phosphorus Interaction on Arsenic-Induced Oxidative Stress in Chickpea Plants. Plant Soil 2009, 314, 211-220. [CrossRef]

48. Suriyagoda, L.D.B.; Dittert, K.; Lambers, H. Mechanism of Arsenic Uptake, Translocation and Plant Resistance to Accumulate Arsenic in Rice Grains. Agric. Ecosyst. Environ. 2018, 253, 23-37. [CrossRef]

(C) 2019 by the authors. Licensee MDPI, Basel, Switzerland. This article is an open access article distributed under the terms and conditions of the Creative Commons Attribution (CC BY) license (http://creativecommons.org/licenses/by/4.0/). 